\title{
İzmir Sokak Lezzetleri
}

\section{Erhan Akarçay*}

İzmir doğumlu olmasam da çocukluğunun, ilk gençliğinin önemlice bir bölümünü İzmir'de yaşamış bir kimse olarak İzmir'in kültürel ikliminin üzerimdeki etkisini her fırsatta dile getiririm. İzmir'deki ortaöğrenim hayatım boyunca yaşadığım evin önünden geçen sokak satıcılarının bağırışları bugün bile kulaklarımda yankılanır.

Belleğimde en çarpıcı olanlarından biri her gün geçen "boyoz"cudur. Nazillili birisi olarak ne olduğunu bilmediğim ve anlamadığım için yediğimi hatırlamıorum; İzmirli okul arkadaşlarımın yediğine de okulun kantininde satıldığına da tanık olmadım. Bu nedenle olsa gerek bugün her yerde bulunabilmesi, İzmir'in sınırlarını aşması halen şaşırtıcı gelir bana. İkincisi soğuk kış akşamlarında kısa bir dönem için kulaklarımıza çarpan bozacının sesidir. Ne olduğunu çok merak edip bir akşam babamın bana cesaret verip aldırdığı ve ilk kez tanıştığım ev yapımı bozadan pek hoşlanmadığımı hatırlarım. Bir başka sokak lezzeti ise okuldaki büfelerde yapılan kumru idi. Şimdilerde "neden daha fazla kumru yemedim ortaokul ve lise hayatım boyunca?" diye hayıflanırım kendi kendime. Okul çıkışlarına macuncu gelirdi ama hiç oralı olmadım. Kim bilir kaç kez Kemeraltı'nda ayaküstü şambali satıcılarının önünden geçtim ama bir kere bile alıp yediğimi anımsamıyorum. Ancak şurası kesin ki İzmir'in yerleşik sokak lezzetleri benim tanık olduğum daha yakın dönemde dahi önemli bir yere sahipti. Bugün sosyal medya "kaşifler"i ile İzmir'den çıkma sokak lezzetleri kumru, İzmir usulü kokoreç, boyoz, şambali, lokma, söğüş Türkiye'de bilinir hale geldi.

Bağımsız bir araştırmacı olan Nejat Yentürk özel olarak yemek tarihimize, genel olarak kültür tarihimize önemli bir katkı sunduğu kitabında yüzyıllar boyu farklı uygarlıklara ev sahipliği yapmış İzmir'in kent tarihine yeme içme odaklı bir yaklaşım sunuyor. Yentürk, Annales Okulu'nun tarihin lineer bir çizgiden oluştuğu tezine karşı çıkarak çok katmanlı yapısına vurgu yaptığı yaklaşımı ve Fernand Braudel'in gündelik yaşamın tarihine odaklandığı çizgiyi benimsiyor. Böylesi bir tarih yaklaşımı ile İzmir'in ayaküstü mutfağının kültür tarihine odaklanıyor. Referanslarında tarihten (Fernand Braudel, Stefanos Yerasimos) sosyolojiye (George Ritzer); yemek kültürü ve tarihi konusunda güncel dergilere (Yemek ve Kültür) ve kitaplara (Priscilla Mary Işın) pek çok yazara ve yayına atıfta bulunuyor. Oldukça geniş bir yelpazede İzmir sokak lezzeti ve mutfağını gözler önüne seriyor. Yazar tıpkı bir arkeolog gibi, tarihten günümüze İzmir'in kadim mutfak kültürünü, kentin belleğini, bunların sokak lezzetleri ekseninde arkeolojisini yaparak gün ışığına çıkartıyor. Böylelikle Yentürk, İzmir özelinde gastronomik değerlerin nasıl etraflıca analiz edilebileceğinin güzel bir örneğini başarılı bir biçimde sunuyor.

* Anadolu Üniversitesi, Sosyoloji Bölümü 
Yazarın “İzmir'in ayaküstü mutfağının kültür tarihi” olarak giriştiği bu çaba kültür tarihinin çok ötesinde eşine az rastlanır bir başucu kitabına kendiliğinden dönüşüyor. Üstelik yemek kültürümüzde tartışma konusu olan "ayaküstü yemek", "sokak lezzetleri" ve 1980'lerden sonra değişen ekonomi politikaları ile toplumsal yaşamımıza giren "fast food" kavramlarıyla ilgili yaşadığımız kafa karışıklığını gidererek önemli bir boşluğu doldurmuş oluyor.

Türkiye'deki yemek kültürüne ilişkin gerek akademik gerekse popüler yayınlarda ayaküstü yiyecekler nedense ihmal edilir. Çok yakın zamana kadar sokakta satılan yiyeceklere ilişkin "hijyenik olmadıkları", "güvenilir bulunmadıkları" gibi önyargıların egemen olduğu görülür. Yazar literatürde var olan çalışmaların ise kent folkloru ve göçle ilintili sosyolojik araştırmalarla sınırlı olduğu ya da "mikrobiyal riskler" açısından ele alındığı eleştirisini yapıyor. Tarihsel perspektifi olan yemek kitaplarının ise son yirmi yılda yaygınlık kazandığını yerinde bir şekilde tespit eden Yentürk, bunlara küreselleşme sonucunda turizm ile sınırlı bir çerçeve içinde gastronomi turizmiyle birlikte ilginin arttığını ileri sürüyor.

Dünyada gıdaya yönelik tüketim eksenli bir ilgi artışı olduğu aşikâr. Olgusal bir gerçeklik olan küreselleşmenin etkisiyle yemek kültürleri benzeşirken dönüşüyor. Buradan hareketle, yemek kültürleri dönüştükçe yerelliklerin yeniden — kimi zaman başkalaşarak — keşfedildiği bir çağda yaşadığımız sonucuna ulaşmak mümkün.

Ayaküstü yemeğin çerçevesi bugün hızla değişiyor. İşin içerisine atıştırmalıklar da dahil edildiğinde, ayaküstü yemek balık ekmekten çiğ köfteye, nohutlu pilavdan midye dolmaya, haşlanmış mısırdan buzda bademe, kokoreçten ekmek arası dönere, kestane kebaba kadar geniş bir yelpazede değerlendirilebilir. ${ }^{1}$ Nazlı Pişkin, fast food'un yabancılaşmayı belirten bir kavramlaştırma olduğunu ileri sürer. Öte yandan ayaküstü yemek, "yiyeceğin kendisinin çabuk hazırlanması, satıcının seyyar esnaf ya da küçük bir dükkân olması, sadece yiyeceğin satın alınmasının hızlı olması, yiyeceğin kendisinin ayakta dikilerek tüketilmesi ya da fiyatının ucuz olması ile sınırlı olmayan; yerel kültüre ait sokak yemeklerini ve tüketimini anlatan bir terim"dir. ${ }^{2}$ Türkiye'de dışarıda yeme pratiklerinin sınıfsal ayrım gözetmeksizin "hızlı" çözülmesi gereken, yenice ritüelleşme aşamasında olduğunu varsaydığımızda Boudan'ın Türkiye'yi “hızlı karın doyurma cenneti" olarak tanımlaması oldukça yerinde. ${ }^{3}$ Zira "hızlı karın doyurma cenneti" olan Türkiye'de lokantalarda dahi servis beklenmez, çabucak yenilebilir, hızlı ödeme yapılabilir ve çekip gidilebilir. A la carte restoranlarda dahi Türkiye'de sabırsız bir tüketicinin olduğu gerçeği kabul edilebilir.

1 Erhan Akarçay, Beslencenin Sosyolojisi: Orta Stmıfların Yeme İçme ve Eğlence Örüntüleri (Ankara: Phoenix Yayınları, 2016), 78.

2 Nazlı Pişkin, “Fast Food Kargaşası Üzerine Bir Değerlendirme: Bir Gün Gelecek Herkes Hamburger mi Yiyecek", Sosyologca 2 (2011): 233-241, burada 234.

3 Christian Boudan, Mutfak Savaşı: Damak Zevkinin Jeopolitiği, çev. Yaşar Avunç (İstanbul: Ayrintı Yayınları, 2006), 183. 
Aylin Öney Tan’a göre Türkiye'deki sokak yiyecekleri çoğunlukla abur cubur değildir. Her şeyiyle yeni baştan hazırlanan, genellikle oldukça sağlıklı, katkı ve koruyucu madde içermeyen yiyeceklerdir; hatta bazı sokak yiyecekleri kentlerde yaşayan insanların gıda teminini önemli ölçüde karşılar. ${ }^{4}$ Öney Tan'ın Türkiye'deki sokak yiyeceklerine ilişkin vurguladığı bir başka sosyolojik yan ise bu yemeklerin göreli olarak ucuz olduğu ancak yoksulla sınırlı bir biçimde ilişkilendirilmemeleri gerektiğidir; zira bunlar toplumdaki tüm tabakaların yiyeceği olarak sınıf ayrımlarını eritir. ${ }^{5}$ Yentürk ise ayaküstü mutfak ritüelinin gastronomik bir deneyim olarak sosyolojik analizini ustalıkla yapıyor:

Sokakta yaşayan, karın doyurmakla sınırlı bir eylem değil, bütün tarihsel ve toplumsal derinlikleriyle bir temastır. İnsanlığın binlerce yılda meydana getirdiği hikâyenin son safhasıyla ilişki kurulur: Yemeğin pişirilmesi seyredilir, kokusu içe çekilir, tadılır, çiğnenir, yutulur, haz alınır. Hikâyenin içine girilir, hikâyenin taşı11cısı olunur. ${ }^{6}$

Ayaküstü mutfak, böylesi bir analizde yemek kültürü ve sosyolojisi içinde yerellikle ilişkisi ve politik bir tutum olması nedeniyle önem kazanır. Küreselleşme dinamiklerinin kültürel düzlemde, özellikle yeme içme kültüründe yayılmacı tutumu günümüz tüketim kültürü içerisinde anlam bulur. Yerel ve küresel olanın diyalektiği içinde sokağın dolayısıyla halkın sahip olduğu ayaküstü mutfak gün geçtikçe bir politik zemin olarak değerlendirilebilir.

Nedim Atilla'nın ifadesiyle İzmir'in zengin mutfak kültürünün arkasında bölgenin eşsiz iklimi, İzmir'in gelmiş geçmiş 30'dan fazla uygarlığın beşiği oluşu yatar.7 İzmir çağlar boyunca farklı dönemlerde göç alan, ticaretin egemen olduğu, Anadolu'da kapitalist dünya ekonomisiyle ilk temas kuran önemli bir liman kentidir. Bu özelliklerinden dolayı yemek kültüründeki çeşitlilik, göçmenlerin kültürel çeşitliliğini de yansıtır. Göçmen bir aileden gelen Yentürk de bu kültürel çeşitliliğin ürünü olarak, sokak gözlemleri ile sokak lezzetlerini keşfe çıkıyor. Sokağın mutfağı, kent sakinlerinin büyük çoğunluğunun bu mutfak ekseninde bir araya gelebildiği ayaküstü yenilen yiyecek, içeceklerle sınırlandırılmış durumda. Yentürk'ün bağımsız bir araştırmacı olarak sorulmayan, gündeme getirilmeyen soruları sorma cesareti gösterebiliyor olması takdire şayan.

Boudan'ın epey bir zaman önce kaleme aldığı kitabının adını "mutfak savaşları" koyması tesadüfi değil; söz konusu mutfak çatışmaları yerküredeki jeopolitik etmenlerle ilgili olsa da yerel ölçekte mikro milliyetçilikler üzerinden anlaşmazlık unsurları haline gelebiliyor. Türkiye'nin politik atmosferi kentlerin mikro milliyetçilikler geliştirebildiği bir zemin yaratmaktadır. Gevrek-simit

4 Aylin Öney Tan, "Turkey", Street Food Around the World: Encyclopedia of Food and Culture içinde, der. Bruce Kraig ve Colleen Taylor Sen (Santa Barbara: ABC Clio, 2013), 362.

5 Öney Tan, “Turkey”, 359.

6 Nejat Yentürk, Ayaküstü İzmir: Sokak ve Fırın Lezzetleri (İstanbul: Oğlak Yayınları, 2018), 41.

7 A. Nedim Atilla, Tarihten Günümüze İzmir Mutfağı (İzmir: İzmir Kent Kitaplığı, 2001), 3. 
gerilimi, boyoz, midye dolma gibi popüler örnekler bu gerilimi İzmir'in "gavur"luğuna kadar tırmandırır. Zira herhangi bir bölgenin, kentin mutfağının sınırlarının ne olacağı konusunda bir uzlaşmazlık halinin, kent milliyetçiliğine uzanacak kadar yoğun yaşandığı "gastronomi kenti" rekabeti içine girdiğimiz bir dönemden geçiyoruz. Yazarın çok isabetli bir biçimde İzmir mutfağının içinin boşaltıldığı fikri, bu mutfağın zeytinyağı, balık, sebze ve yabani otlara indirgenmesi, kentin göçmen, çokkültürlü unsurlarını göz ardı etmek anlamına gelir. Yentürk'e göre "arayanı soranı kalmayan" pek çok ayaküstü lezzeti İzmir'in mutfak kültürünün zenginliğinin tarihsel uğraklarını oluşturur. Bunlardan iftazma, ramazan simidi, bir ayaküstü atıştırmalık olarak mumlu balık yumurtası ilk akla gelenlerden.

Yentürk'ün Ayaküstü İmir: Sokak ve Fırın Lezzetleri kitabının ne kadar titiz bir çalışmanın ürünü olduğunun en somut kanıtlarından biri boyozun kökenlerine ilişkin tartışmayı ustalıkla yapmış olmasıdır. Şirvani'den Evliya Çelebi'ye ve Ömer Lütfi Barkan'a tarihsel kaynakların taranması neticesinde elde ettiği bulgularla börek, katmer, şabat, tahinli ev boyozu ve çarşı boyozunun İber Yarımadası́ndan olası yolculuğu üzerine yeni sorulara yeni yanıtlar vermemizi sağlıyor. Yentürk'ün ödüllü kitabı, Türkiye'de gastronomi dünyası, mutfak ve yemek kültürü akademisyenleri için başucu kitabı olma özelliği taşıyor. Gerek geçmişten bugüne İzmir kent kültürünün kayıt altına alınması, gerekse en güçlü bellek taşıyıcılarından biri olan yemek, tat üzerinden bellek çalışmalarına dahil edilebilecek yanıyla Yentürk'ün İzmir ve Türkiye gastronomisi için literatüre klasik bir eser kazandırdığı ifade edilebilir. Bu çalışmanın bir örnek oluşturacağını, Türkiye'deki mutfak kültürü zengin kentler açısından benzer çalışmaların yapılması için bir teşvik unsuru olacağına inanıyorum. Kişisel olarak Yentürk'ün bundan sonraki çalışmalarını merakla bekleyeceğim.

Nejat Yentürk, Ayaküstü Izmir: Sokak ve Fırın Lezzetleri (İstanbul: Oğlak Yayıncılık, 2018), 479 sayfa, ISBN-13: 978-975-32-9941-1. 